\title{
A human, ATP-independent, RISC assembly machine fueled by pre-miRNA
}

\author{
Elisavet Maniataki and Zissimos Mourelatos ${ }^{1}$ \\ Department of Pathology, Division of Neuropathology, University of Pennsylvania School of Medicine, \\ Philadelphia, Pennsylvania 19104, USA
}

\begin{abstract}
RNA interference (RNAi) is mediated by RNA-induced silencing complexes (RISCs), which are guided by microRNAs (miRNAs) or short interfering RNAs (siRNAs) to cognate RNA targets. In humans, the catalytic engine of RISC is a ribonucleoprotein formed by the Argonaute2 (Ago2) protein and either miRNA (miRNP) or siRNA (siRNP). The Dicer nuclease produces mature miRNAs and siRNAs from pre-miRNAs and double-stranded RNA (dsRNA), respectively, and associates with Ago2. Here, we studied the assembly of human RISC by presenting pre-miRNA to immunopurified complexes that contain Ago2, Dicer, and TRBP. Mature miRNAs were produced in an ATP-independent manner and guided specific cleavage of cognate RNA targets in a pattern that is typical of RISC. This de novo formed RISC activity dissociated from Dicer. The asymmetry of the RISC loading process was fully recapitulated in this system, which, however, could not efficiently assemble RISC from siRNA duplexes. Our findings demonstrate that, in humans, a miRNA loading complex (miRLC) is formed by Ago2 and Dicer prior to their encounter with pre-miRNA. We suggest that the miRLC couples the processing of the pre-miRNA substrate to the unwinding of the product and that after loading of the mature miRNA to Ago2, the miRLC disassembles and the miRNP is released.
\end{abstract}

[Keywords: miRNA; miRNP; Dicer; Argonaute; siRNA; RNAi]

Supplmental material is available at http://www.genesdev.org.

Received June 21, 2005; revised version accepted November 3, 2005.

MicroRNAs (miRNAs) are $\sim 22$-nucleotide (nt) regulatory RNAs (Lee et al. 1993; Reinhart et al. 2000; Lagos-Quintana et al. 2001; Lau et al. 2001; Lee and Ambros 2001; Mourelatos et al. 2002; Nelson et al. 2003; Ambros 2004; Bartel 2004). Animal miRNAs are initially transcribed by RNA polymerase II as longer transcripts known as pri-miRNAs (Lee et al. 2004a) and are processed in the nucleus by the RNase III nuclease Drosha (Lee et al. 2003) in conjunction with Pasha, a protein that contains two double-stranded RNA-binding domains (dsRBDs), into 70 -nt pre-miRNAs (Lee et al. 2002, 2003; Denli et al. 2004; Gregory et al. 2004; Han et al. 2004; Landthaler et al. 2004). pre-miRNAs adopt a stem-loop structure and contain a 5 '-phosphate and a 2 -nt 3 '-overhang (Lee et al. 2003), and are exported to the cytoplasm (Lee et al. 2002; Yi et al. 2003; Bohnsack et al. 2004; Lund et al. 2004; Zeng and Cullen 2004), where the Dicer nuclease excises mature miRNAs from one of the stems of the premiRNA /Grishok et al. 2001; Hutvagner et al. 2001; Ketting et al. 2001; Knight and Bass 2001). Mature, singlestranded miRNAs assemble with additional proteins into RNA-induced silencing complexes (RISCs) or

${ }^{1}$ Corresponding author.

E-MAIL mourelaz@uphs.upenn.edu; FAX (215) 746-0285.

Article and publication are at http://www.genesdev.org/cgi/doi/10.1101/ gad.1384005.
miRNPs (Hammond et al. 2001; Hutvagner and Zamore 2002; Martinez et al. 2002; Mourelatos et al. 2002; Murchison and Hannon 2004). Argonaute (Ago) proteins are $\sim 95-\mathrm{kDa}$ proteins that bind to miRNAs directly and form the core proteins of RISCs and miRNPs (Hammond et al. 2001; Hutvagner and Zamore 2002; Martinez et al. 2002; Mourelatos et al. 2002; Meister and Tuschl 2004; Murchison and Hannon 2004). Multiple Ago paralogs typically exist in many organisms (Carmell et al. 2002). Dicer processing of double-stranded RNA (dsRNA) (Bernstein et al. 2001; Zhang et al. 2004) generates short interfering RNAs (siRNAs) (siRNA duplexes), which are 22 -nt dsRNA fragments that contain 5 ' -phosphates and 2-nt 3 '-overhangs (Hamilton and Baulcombe 1999; Elbashir et al. 2001). Like miRNAs, singlestranded siRNAs bind to Ago proteins directly and assemble into RISCs (Martinez et al. 2002; Schwarz et al. 2002).

miRNAs and siRNAs function by base-pairing with their RNA targets, and direct target RNA endonucleolytic cleavage if the $5^{\prime}$-end of the miRNA or the siRNA base-pairs with its RNA target and if the base-pairing includes nucleotides 10 and 11 , as measured from the 5 '-phosphate, of the miRNA or siRNA (Elbashir et al. 2001). This is the mechanism of target RNA degradation in RNA interference (RNAi) (Fire et al. 1998; Elbashir et al. 2001). Ago2 (previously known as eIF2C2) is the en- 
donuclease that cleaves the RNA target in a miRNA- or siRNA-dependent manner (Liu et al. 2004; Meister et al. 2004; Rand et al. 2004; Song et al. 2004; Rivas et al. 2005).

The assembly of RISCs and miRNPs is of paramount importance in RNA silencing pathways mediated by small RNAs. The biochemistry of RISC assembly from siRNA duplexes has been studied mostly in Drosophila melanogaster. Flies contain two Dicer proteins (Dcr-1 and Dcr-2) with distinct functions. Dcr-1 is responsible for miRNA production and is an essential protein that is required for fly development, whereas Dcr-2 is required for siRNA production, but flies lacking Dcr-2 develop normally (Lee et al. 2004b). Addition of siRNA duplexes to Drosophila embryo or ovary lysates triggers an ordered assembly of RISC (Pham et al. 2004; Tomari et al. 2004a,b). siRNA duplexes are initially bound to a protein complex known as the RISC loading complex (RLC) that contains Dcr-2 and R2D2, a dsRBD protein, and possibly other proteins (Pham et al. 2004; Tomari et al. 2004a,b; Tomari and Zamore 2005). The RLC senses the thermodynamic asymmetry of the siRNA duplex, and R2D2 binds the siRNA end that shows the stronger dsRNA binding, while Dcr-2 binds the opposite end of the duplex (Tomari et al. 2004b). Such orientation ensures that the siRNA that is derived from the "looser" end of the siRNA duplex (the end that is bound to Dcr-2) will become incorporated in RISC as the siRNA guide strand, while the other (passenger) strand is excluded from RISC (Tomari et al. 2004b). This thermodynamic asymmetry also guides RISC loading in mammals and applies to siRNAs derived from siRNA duplexes and to miRNAs derived from pre-miRNAs (Khvorova et al. 2003; Schwarz et al. 2003). Drosophila Ago2 joins the RLC/ siRNA duplex at a later time (Pham et al. 2004; Tomari et al. 2004b), and unwinding of the siRNA duplex requires ATP (Nykanen et al. 2001; Tomari et al. 2004b; Tomari and Zamore 2005) and Ago2 (Okamura et al. 2004) and appears to occur concomitantly with loading of Ago2 with single-stranded siRNA (Tomari et al. 2004b; Tomari and Zamore 2005). The final fly RISC, assembled from siRNA duplexes, is termed "holoRISC," sediments as an $80 \mathrm{~S}$ complex, and contains single-stranded siRNAs bound to Ago2, the RLC proteins Dcr-2, R2D2, and other proteins, and likely associates with ribosomes (Pham et al. 2004). In flies, premiRNA processing requires in addition to Dcr-2 a recently identified dsRBD protein termed loquacious (loqs), a paralog of R2D2 (Forstemann et al. 2005; Jiang et al. 2005; Saito et al. 2005). The loquacious human homolog TRBP binds to Dicer and Ago2, but there are different interpretations of the role of TRBP in miRNA processing or function (Chendrimada et al. 2005; Haase et al. 2005).

How RISCs are assembled from pre-miRNAs in humans has not been conclusively demonstrated. Here, we describe a human RISC assembly pathway in which premiRNA is the source of the miRNA. This pre-miRNAfueled human RISC assembly line differs from the previously reported fly RISC assembly by siRNAs, in terms of the sequence of events, energy requirements, and the final RISC product.

\section{Results \\ Ago2-associated Dicer processes pre-miR-30a to mature miRNA}

We generated a Human Embryonal Kidney 293 (293) cell line that stably expresses mouse Ago2 containing an Nterminal Flag-tag, under the control of a tetracyclineinducible promoter. The predominant RNAs that associate with Flag-Ago2 are not miRNAs but the mitochondrial tRNA for Methionine (mt-tRNA ${ }^{\text {Met }}$ ) (Maniataki and Mourelatos 2005). Similarly, we found that Ago2 carrying a myc epitope tag at the $\mathrm{N}$ terminus or at the $\mathrm{C}$ terminus also associates mostly with mt-tRNA ${ }^{\text {Met }}$, when expressed in 293 cells (Maniataki and Mourelatos 2005). This is in contrast to endogenous human or mouse Ago2, which associate primarily with mature miRNAs (Mourelatos et al. 2002). We hypothesized that the overexpressed, epitope-tagged Ago2 was "arrested" at a step preceding the generation of mature miRNAs, and we sought to investigate the functional properties of the complex(es) formed by epitope-tagged Ago2.

We performed immunoprecipitations using agarose beads conjugated with anti-Flag antibody, from the FlagAgo2-expressing 293 cells, after tetracycline induction, and from the parental 293 cells. We analyzed the immunoprecipitates on $4 \%-12 \%$ NuPAGE, and we visualized the proteins by silver staining. As shown in Figure 1A, there were two prominent bands at $\sim 95 \mathrm{kDa}$ and $\sim 200$ $\mathrm{kDa}$ and a less prominent band at $\sim 90 \mathrm{kDa}$ that were specifically seen in the immunoprecipitates from the Flag-Ago2 cell line. Other, less prominent bands were seen, but these were not consistently present in other experiments. In contrast, the $\sim 95-\mathrm{kDa}$ and $\sim 200-\mathrm{kDa}$ bands were always found in the immunoprecipitates from the Flag-Ago2 cell line. The most plausible candidates for these proteins were Flag-Ago2 ( 95 kDa), Dicer ( 200 kDa), and HSP90 ( 90 kDa), as it was previously reported that Ago 2 coprecipitates with Dicer and HSP90 (Hammond et al. 2001; Tahbaz et al. 2001, 2004; Doi et al. 2003; Liu et al. 2004). Human TRBP has also been reported to associate with Dicer (Chendrimada et al. 2005; Haase et al. 2005). To confirm the association of all those proteins with Ago2 in our experimental conditions, we performed Western blots using antibodies against these proteins and found that Dicer, HSP90, and TRBP coprecipitated with Flag-Ago2 in the 293 cell line (Fig. 1B).

The presence of Dicer prompted us to investigate whether the immunopurified Ago2 complex was capable of pre-miRNA processing. We incubated the immunoprecipitates from the Flag-Ago2 or the parental cell line with $5^{\prime}$-end-labeled synthetic pre-miR-30a RNA. The sequence and structure of the synthetic pre-miR-30a RNA (shown in Fig. 2A) mimicked the natural one, after Drosha processing, and contained a 2-nt 3 '-overhang and a radiolabeled 5'-phosphate. As shown in Figure 1C, a ma- 
A

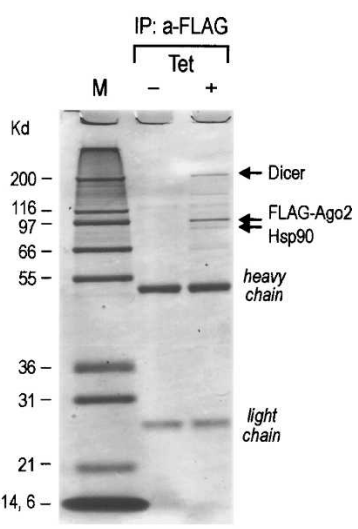

B
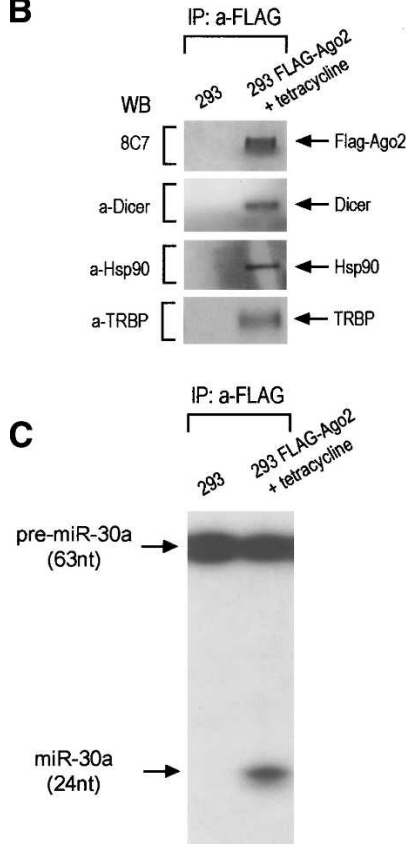

Figure 1. Immunopurified Flag-Ago2 contains Dicer and displays pre-miRNA processing activity. (A) 293 cells were stably transfected with Flag-Ago2 under the control of a tetracyclineinducible promoter. Immunoprecipitations (IP) were performed with anti-Flag antibody from noninduced $(-)$ and from tetracycline-induced $(+) 293$ cells, and the immunoprecipitates were resolved on a $4 \%-12 \%$ NuPAGE and stained with silver. $(B)$ Immunoprecipitates from $A$ were analyzed by Western blot with the indicated antibodies. $(C)$ Immunoprecipitates from $A$ were incubated with a synthetic pre-miR-30a (sequence shown in Fig. 2A) containing a radiolabeled 5 -phosphate, and the reaction products were analyzed on a $15 \%$ UREA-PAGE and visualized by autoradiography.

jor 24-nt product (and a minor at $23 \mathrm{nt}$, better shown in Fig. 2) was efficiently processed from the 63-nt substrate, indicating that Ago2-associated Dicer was able to properly process miR-30a-5p from pre-miR-30a.

miR-30a-5p production does not depend on the catalytic activity of Ago2

In order to demonstrate that pre-miR-30a processing by immunopurified Ago2 does not depend on its catalytic activity, we tested an Ago2 mutant that is inactive in RNA target cleavage. We transfected 293T cells with human, wild-type myc-Ago2 (myc-Ago2-WT) and with a point mutant that abolishes target RNA cleavage (mycAgo2-D669A) (Liu et al. 2004). A myc-hnRNP-Q3 construct, expressing an RNA-binding protein (Mourelatos et al. 2001), was used as a negative control. We performed immunoprecipitations with anti-myc-conjugated agarose beads, and incubated the beads with $5^{\prime}$-end-labeled pre-miR-30a. As shown in Figure 2A, both mycAgo2-WT and myc-Ago2-D669A, but not myc-hnRNPQ3, processed pre-miR-30a to miR-30a-5p, demonstrating that the pre-miRNA processing activity of the immunoprecipitates depends on the presence of Ago2 but not on its enzymatic activity.

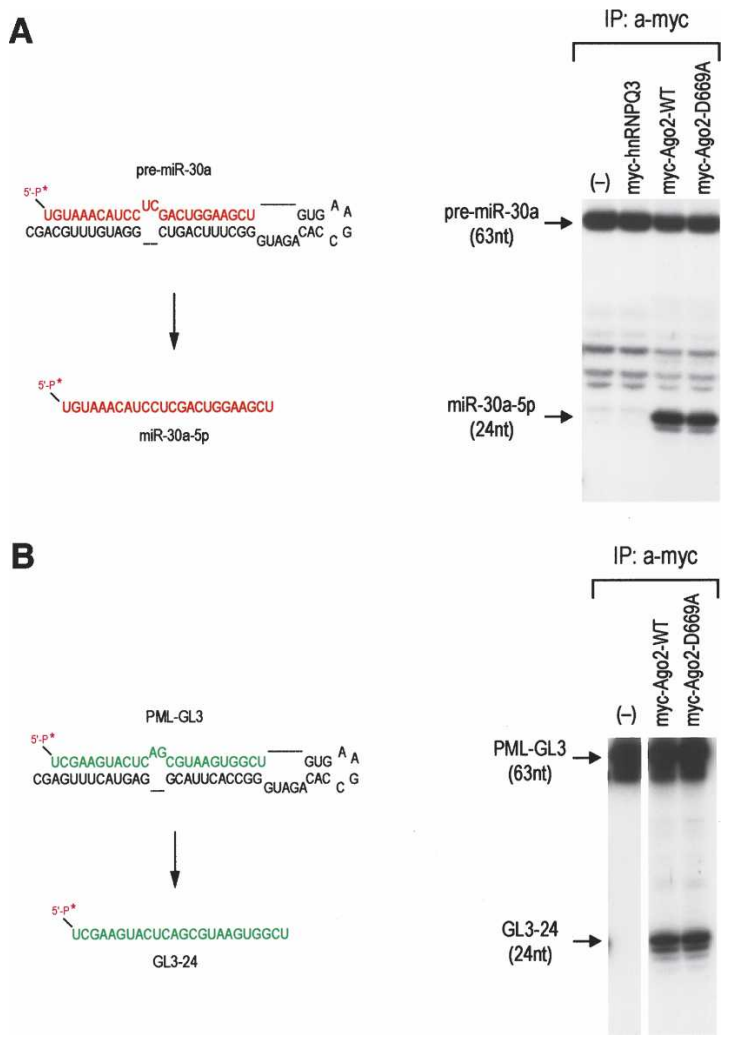

Figure 2. Immunopurified myc-Ago2, both wild type and catalytically inactive, process pre-miR-30a and artificial PML RNA. $(A$, left panel) Primary and secondary structure of premiR-30a used in the processing reactions. The $5^{\prime}$-end-labeled mature miR-30a-5p generated after processing is shown. Red asterisk indicates the radiolabeled 5 '-phosphate. (Right panel) Immunoprecipitations were performed with anti-myc antibody from 293 T cells transfected with myc-tagged wild-type Ago2 (myc-Ago2-WT), with a catalytically inactive Ago2 mutant (myc-Ago2-D669A), or with myc-hnRNPQ3 (negative control). The immunoprecipitates were incubated with 5'-end-radiolabeled synthetic pre-miR-30a. Reaction products were analyzed on a $15 \%$ UREA-PAGE and visualized by autoradiography. $(B$, left panel) Primary and secondary structure of an artificial PML RNA (PML-GL3) used in the processing reactions. (Right panel) Processing reactions with 5 '-end-radiolabeled PML-GL3. 


\section{A designed pre-miRNA-like RNA substrate for Ago2-associated Dicer}

Next, we tested if the myc-Ago2 immunoprecipitates displayed the substrate recognition and processing properties expected of Dicer. We designed a pre-miRNAlike RNA (PML-GL3) that maintained the structural features of pre-miR-30a but not the mature miRNA sequences. In PML-GL3, the first 21 nt of the 24-nt miR-30a-5p sequence were replaced with the GL3 sequence (derived from firefly luciferase), and the miR-30a$3 p$ sequence was replaced with a sequence that basepaired with GL3, preserving the mismatches, as well as the 2-nt overhang at the $3^{\prime}$-end (see Fig. 2B). We tested whether PML-GL3 could be processed by the myc-Ago2 immunoprecipitates. As shown in Figure 2B, both mycAgo2-WT and myc-Ago2-D669A immunoprecipitates processed 5'-end-labeled PML-GL3 into mature GL3-24 "miRNA" with comparable efficiency to pre-miR-30 processing. These results demonstrate that the immunopurified Dicer/myc-Ago2 complex generates mature
miRNAs after recognizing the structural features of premiRNAs.

Specific cleavage of cognate RNA targets by myc-Ago2 immunoprecipitates preincubated with pre-miRNAs

We next asked whether the mature miRNA produced by the Ago2-bound Dicer could be functionally loaded on Ago2. To test this, we developed a two-step experimental protocol that consisted of a pre-miRNA processing reaction followed by a target RNA cleavage reaction (Fig. 3A). For the first reaction, the myc-Ago2 beads were incubated with cold, 5'-phosphorylated premiRNA, followed by washes to remove the remaining substrate as well as any product not bound to the beads. For the second reaction, the washed beads were incubated with a $5^{\prime}$-end-labeled, cognate RNA target. We reasoned that if the miRNAs produced during the first step were functionally loaded onto Ago2, then the Ago2miRNA ribonucleoprotein would be able to cleave the
A

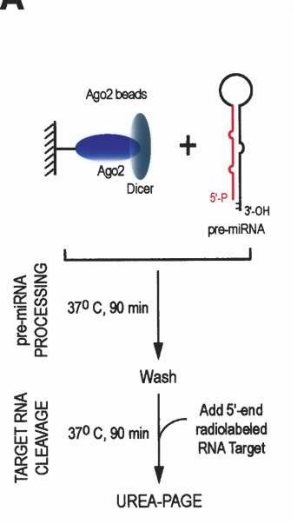

B
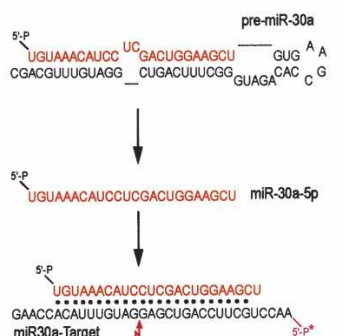

miR300-Target

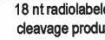

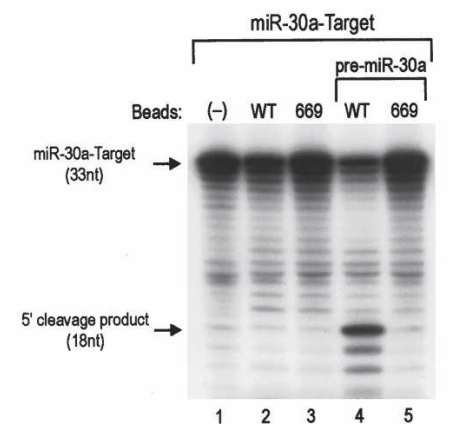

C

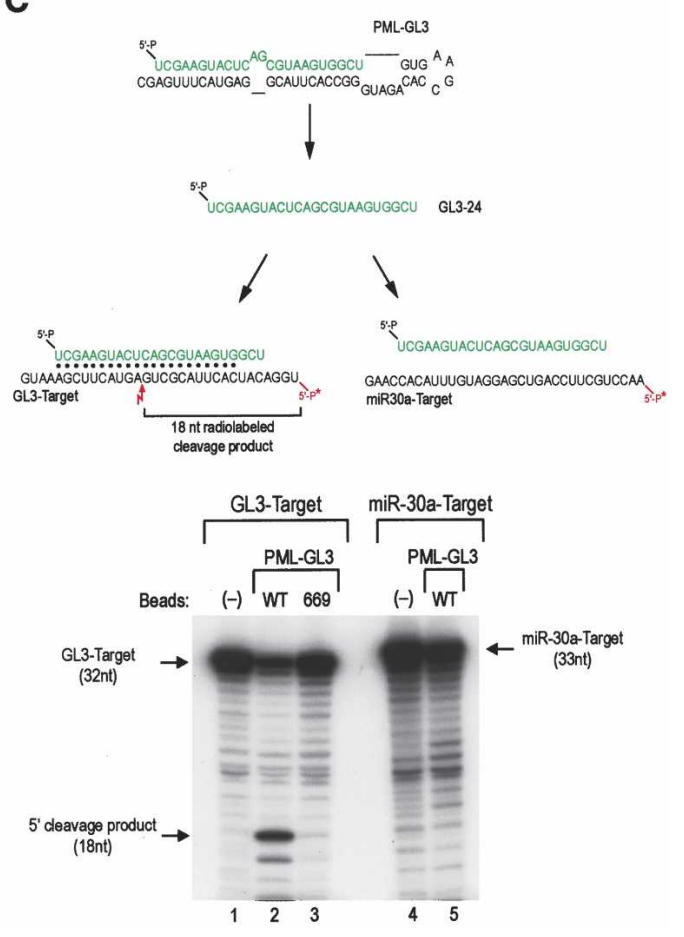

Figure 3. Assembly of functional RISCs from immunopurified myc-Ago2 and synthetic pre-miRNA. (A) Schematic of the two-step experimental protocol used to test RISC loading by pre-miRNA. (B) RISC loading assay performed with cold, 5'-phosphorylated pre-miR-30a. (B, top panel) Sequences of the two RNAs used (pre-miR-30a and cognate Target for miR-30a) and of the mature miRNA (mir-30a-5p) produced from processing of pre-miR-30a. Red asterisk indicates the radiolabeled 5'-phosphate of the RNA target; the lightning bolt shows the position of mir-30a-5p-mediated target RNA cleavage. (Bottom panel) Agarose beads containing immunopurified myc-Ago2, either wild-type (WT) or the catalytically inactive mutant D669A (669), were first incubated in the presence of unlabeled pre-miR-30a (lanes 4,5) or in its absence (lanes 2,3). The beads were then washed and incubated with $5^{\prime}$-end-labeled miR-30a-Target. The first lane (-) shows input target RNA. (C) RISC loading assay performed with cold, 5'-phosphorylated PML-GL3. (Top panel) Sequences of the RNAs used and of the mature GL3-24 produced from processing of PML-GL3. (Bottom panel) Agarose beads containing myc-Ago2, wild type (WT) or D669A mutant (669), were first incubated with unlabeled PML-GL3. The beads were then washed and incubated either with 5'-end-labeled GL3-Target (lanes 2,3) or with 5'-end-labeled miR-30a-Target (lane 5), which served as the target recognition-specificity control. Lanes 1 and $4(-)$, show input target RNAs. RNA was analyzed by $17.5 \%$ UREAPAGE and visualized by autoradiography. 
cognate RNA target across from the middle of the guide miRNA.

As a processing substrate we used unlabeled, 5' -phosphorylated synthetic pre-miR-30a, while the cleavage substrate was a 5' -end-labeled, 33-nt RNA (miR-30a-Target) complementary to miR-30a-5p (see Fig. 3B). We tested with this experimental setup the myc-Ago2-WT and myc-Ago2-D669A immunoprecipitates. When premiR-30a was omitted from the processing reaction, there was no target RNA cleavage (Fig. 3B, lanes 2,3), indicating the absence of substantial endogenous cleavage activity toward the miR-30a-Target in our experimental setup. This was most likely due to negligible amounts of endogenous miR-30a-5p bound to the myc-Ago 2 used in these assays. However, when pre-miR-30a was added to the processing reaction, the miR-30a-Target was cleaved by myc-Ago2-WT (Fig. 3B, lane 4) but not by the catalytically inactive myc-Ago2-D669A mutant (Fig. 3B, lane 5). When instead of pre-miR-30a, PML-GL3 was used, the myc-Ago2-WT immunoprecipitate, but again not myc-Ago2-D669A, efficiently cleaved an RNA target complementary to the GL3-24 "miRNA" (Fig. 3C, lanes $2,3)$. However, when myc-Ago2-WT was incubated with PML-GL3, it was unable to cleave the miR-30a-Target (Fig. 3C, lane 5).

These experiments demonstrate specific cleavages of cognate RNAs, in a pattern expected for RISC, that is, across the middle of mature miR-30a-5p and GL3-24
miRNAs. Target RNA cleavages were dependent on the catalytic activity of Ago2. We can therefore conclude that these RNA targets are cleaved by authentic RISC that is assembled when the small RNA processing products of the Ago2-associated Dicer are loaded on Ago2.

\section{Asymmetric loading of processing products on human RISC}

We then tested whether RISC assembly by the immunopurified myc-Ago2 complex recapitulated the asymmetric loading of miRNAs in RISCs. pre-let-7a-3 was chosen as the processing substrate because of the asymmetry it displays as an in vivo miRNA donor for RISC: In humans and flies, high amounts of let-7a are detected but not its let-7 $a^{\star}$ partner (Schwarz et al. 2003), despite the fact that recombinant Dicer equally produces let-7a and let-7a* from pre-let-7a-3 (Zhang et al. 2004). We prepared prelet-7a-3 that was $5^{\prime}$-end labeled (Fig. 4A, lane 1) or 3 '-end labeled with pCp (Fig. 4A, lane 3), and incubated them with myc-Ago2 immunoprecipitates. Equivalent amounts of let-7a (Fig. 4A, lane 2) and let-7a* (Fig. 4A, lane 4) were produced, confirming that Ago2-associated Dicer cleaved the pre-let-7a-3 symmetrically. To determine which of the two small RNAs (let-7a or let-7a*) assembled into functional RISC, we designed two target RNAs complementary to each of the two small RNAs (Fig. 4B) and tested them in cleavage reactions using cold

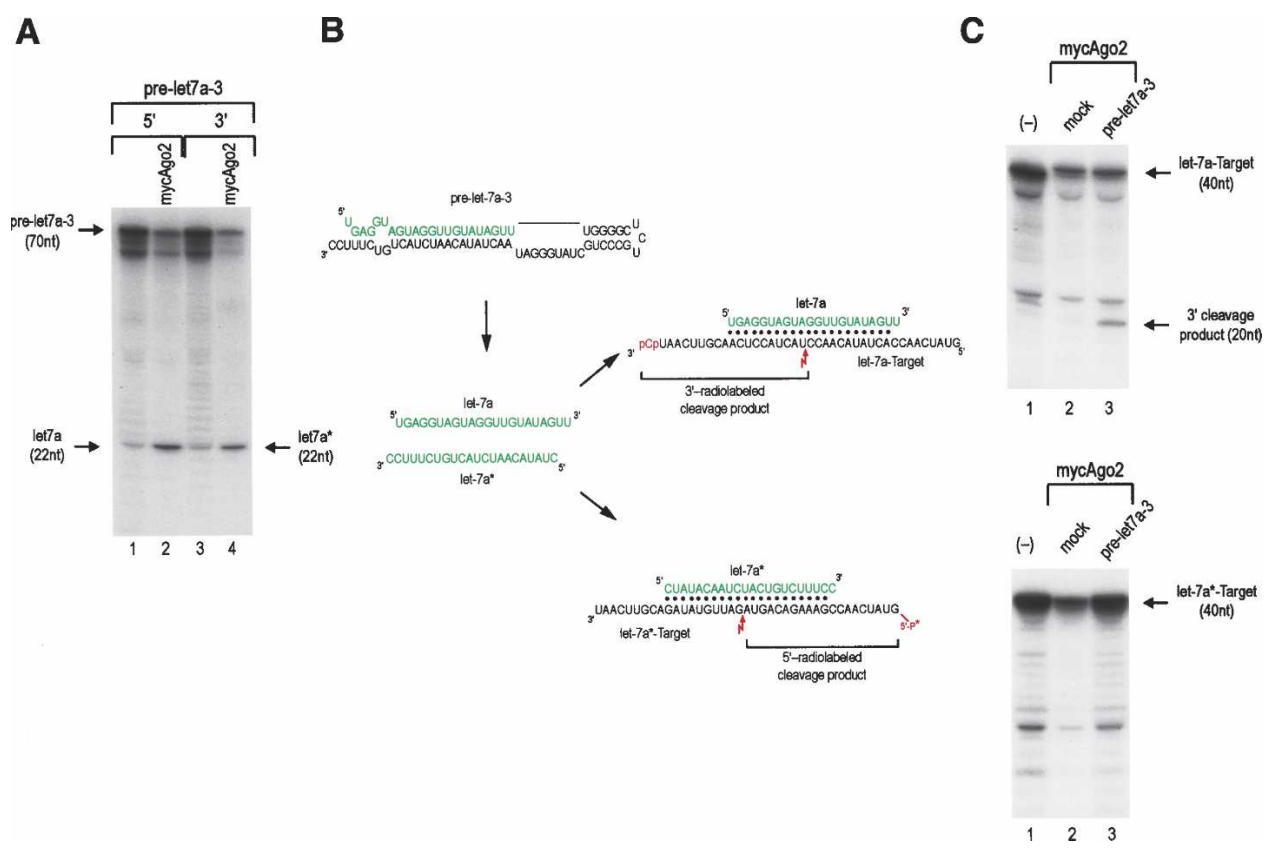

Figure 4. Asymmetric loading of pre-miRNA processing products on RISC. (A) pre-let-7a-3 processing assay. 5'-end-labeled prelet7a-3 (lane 1) or 3'-end-labeled pre-let-7a-3 (lane 3) was incubated with myc-Ago2 beads, and the reaction products were analyzed on a $15 \%$ UREA-PAGE; the miRNAs produced (lanes 2,4) are indicated. (B) Sequence of pre-let-7a-3, its processing products (let-7a and let-7 $\mathrm{a}^{\star}$ ), and the corresponding RNA targets (let-7a-Target and let-7a ${ }^{\star}$-Target). The radiolabeled $5^{\prime}$-phosphate of let-7 ${ }^{\star}-$ Target and pCp (3'-end) of let-7a-Target are shown in red. (C) RISC loading assays with pre-let7a-3. (Top panel) 3'-end-labeled let-7a-Target (unreacted in lane 1) was incubated with mock preincubated myc-Ago2 beads (lane 2) and with myc-Ago2 beads that were preincubated with pre-let7a-3 (lane 3). (Bottom panel) 5'-end-labeled let-7a*-Target (unreacted in lane 1) was incubated with mock myc-Ago2 beads (lane 2) and with myc-Ago2 beads that were preincubated with pre-let7a-3 (lane 3). 
pre-let-7a in the two-step experimental system described above. The let-7a-Target was $3^{\prime}$-end labeled and the let$7 \mathrm{a}^{\star}$-Target was $5^{\prime}$-end labeled. As shown in Figure 4C, the let-7a-target was cleaved by myc-Ago 2 immunoprecipitates preincubated with cold pre-let-7a-3 (Fig. 4C, top panel, lane 3). However, myc-Ago2 beads, preincubated with pre-let-7a-3, were unable to cleave the let-7a*-Target (Fig. 4C, bottom panel, lane 3). These results demonstrate that the myc-Ago2 immunoprecipitates are able to select a miRNA against its miRNA* partner and thus contain a RISC loading machine that recapitulates the asymmetry of the RISC loading process.

The machine that loads miRNAs on RISC does not use corresponding siRNA duplexes efficiently

The Hannon lab has previously reported that myc-Ago2 immunoprecipitates are able to assemble RISC from single-stranded siRNA but not from siRNA duplexes (Liu et al. 2004). We compared the ability of siRNA and pre-miRNA for RISC assembly, using as a basis for our siRNA design the 24-nt product of PML-GL3 processing. To the myc-Ago2-WT immunoprecipitates we added PML-GL3 (containing a 5' -phosphate), or single-stranded GL3-24 RNA (containing a 5'-phosphate), or a GL3 siRNA duplex (containing 5'-phosphates and 2-nt 3'overhangs, with the antisense strand being complementary to the GL3-Target) (see Fig. 5A). We prepared two sets of reactions: one with no added ATP/GTP and another with $1 \mathrm{mM}$ ATP and $0.2 \mathrm{mM}$ GTP. As shown in Figure 5A, addition of a GL3-siRNA duplex was unable to generate functional RISC when added to immunopurified myc-Ago2-WT even when excess ATP/GTP was present in the reaction (Fig. 5A, lanes 4,5), whereas addition of single-stranded GL3-24 RNA was able to generate a functional Ago2-GL3-24 ribonucleoprotein that cleaved a complementary RNA target (GL3-Target) (Fig. $5 \mathrm{~A}$, lanes 6,7$)$. These results are consistent with the findings from the Hannon lab showing that single-stranded RNAs containing 5'-phosphates, but not siRNA duplexes, can be loaded on RISC from immunopurified myc-Ago2 complexes (Liu et al. 2004).

\section{Human RISC assembly by pre-miRNAs} is ATP-independent

The immunoprecipitates used for the experiments described above contained very small amounts of ATP ( 4 $\mathrm{nM}$ ), as determined by luminescence-based ATP measurements. Furthermore, the buffers used did not contain ATP, other nucleotides, or other putative sources of energy (such as NADH), suggesting that pre-miRNA processing and Ago2 loading by immunopurified Ago2/ Dicer-containing complexes might be ATP-independent.

To address this possibility more thoroughly, we treated the myc-Ago2-WT immunoprecipitates with glucose and hexokinase to hydrolyze any residual ATP. We measured the concentration of ATP in these reactions, and it was $<50 \mathrm{pM}$. We also observed that washing the
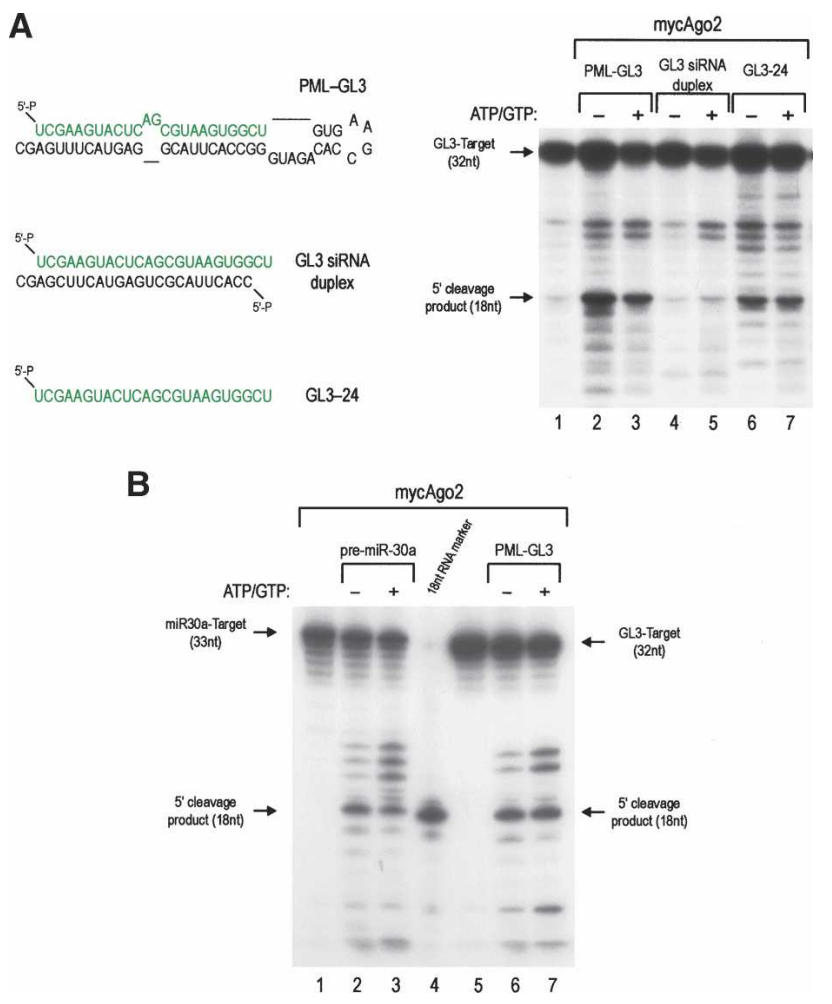

Figure 5. Immunopurified myc-Ago2 complexes can generate RISC from pre-miRNA, but not from corresponding siRNA duplex, regardless of ATP amounts. (A, left panel) Synthetic RNAs used for RISC assembly by immunopurified myc-Ago2-WT; all RNAs contained 5'-phosphates. Sequences shown in green are complementary to the GL3-Target RNA. (Right panel) Agarose beads containing immunopurified, wild-type myc-Ago2 were incubated with cold, PML-GL3 RNA in the absence (lane 2) or presence of $1 \mathrm{mM}$ ATP and $0.2 \mathrm{mM}$ GTP (lane 3); or with GL3 siRNA duplex without (lane 4) or with (lane 5) ATP/GTP; or with single-stranded GL3-24 RNA, without (lane 6) or with (lane 7) ATP/GTP. The beads were then washed and incubated with 5 '-end-radiolabeled GL3-Target RNA. The first lane shows unreacted GL3-Target RNA. RNA was analyzed as in $A$. (B) Agarose beads containing immunopurified, wild-type mycAgo2 complexes were depleted of ATP by extensive washings. The beads were used in RISC loading and cognate target cleavage reactions with cold, $5^{\prime}$-phosphorylated and gel-purified premiR030a or PML-GL3 in the absence (lanes 2,6) or the presence (lanes 3,7) of $2 \mathrm{mM}$ ATP and 0.4 mM GTP. The 5'-end-labeled RNA targets (lanes 1,5 show unreacted targets) were also gelpurified. A synthetic $5^{\prime}$-end-labeled 18-nt RNA oligo in lane 4 served as a size marker. RNA was analyzed by $17.5 \%$ UREAPAGE and visualized by autoradiography.

beads was sufficient to reduce the ATP concentration to negligible amounts $(<50 \mathrm{pM})$. We gel-purified the premiR-30a and the PML-GL3 RNAs after 5'-phosphorylation with ATP and T4 polynucleotide kinase. The 5'end-labeled miR-30a-Target and the GL3-RNA-Target were also gel-purified. As shown in Figure 5B, elimination of ATP from the RISC assembly reaction did not have any effect on the subsequent target RNA cleavage reaction, either when pre-miR-30a (lane 2) or when PMLGL3 (lane 6) was used with the myc-Ago2-WT immuno- 
precipitates. Addition of $2 \mathrm{mM}$ ATP and $0.4 \mathrm{mM}$ GTP (Fig. 5B, lanes 3,7) in the assembly reaction did not enhance target RNA cleavage. These results indicate that RISC assembly from pre-miRNAs does not require ATP.

\section{ATP does not affect the target cleavage reaction}

To investigate how the addition of ATP in the target cleavage reaction affects its rate, we incubated the mycAgo2 immunoprecipitates (containing 200 nM Ago2Dicer complex, assessed by silver staining) with cold PML-GL3 (400 nM) to allow RISC assembly. The beads were washed and were divided equally in two tubes and incubated with radiolabeled GL3-Target (10 nM) in the absence or presence of $1 \mathrm{mM}$ ATP and $0.2 \mathrm{mM}$ GTP. Equal-volume aliquots were removed from the reactions at various time points (shown in Fig. 6), and the reaction products were analyzed by denaturing electrophoresis, quantified, and plotted over time. As shown in Figure 6, target cleavage proceeded at equal rates in the absence or presence of ATP/GTP. Since the Ago2/Dicer complex is in excess of the target, these results show that the RISC formed acts as a single-turnover enzyme.
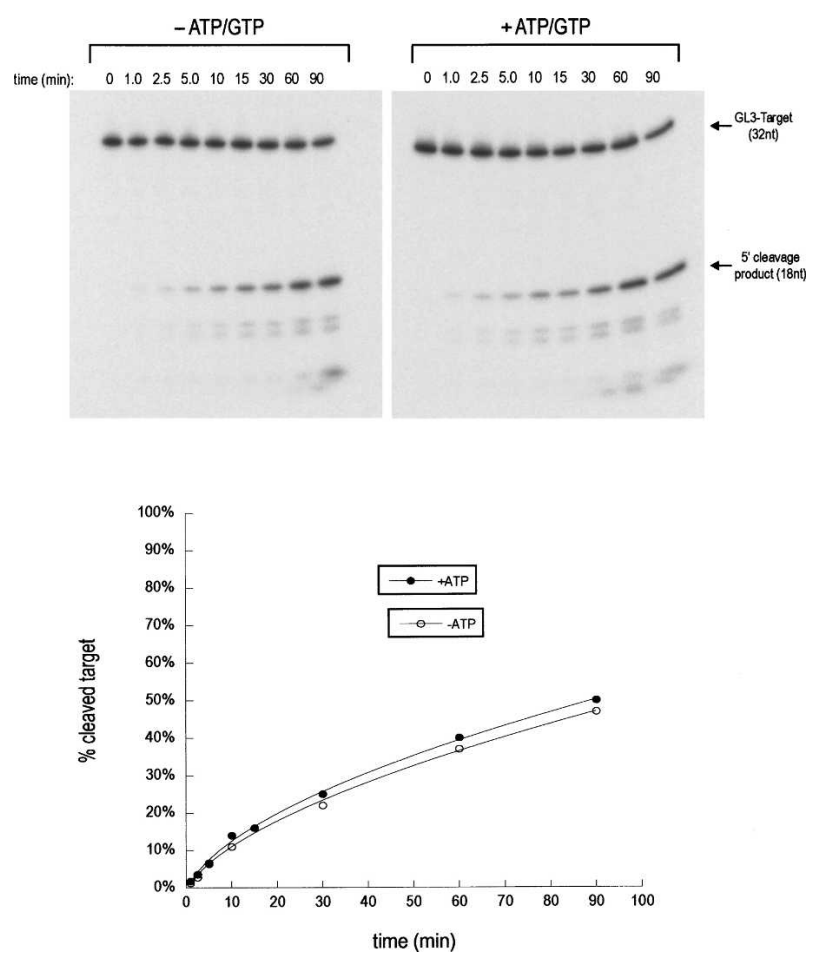

Figure 6. ATP does not affect the rate of target cleavage. (Top) RISCs were assembled with myc-Ago2 immunoprecipitates and cold PML-GL3 (as described in Fig. 3) and were incubated with 5 '-end-labeled GL3-target RNA $(10 \mathrm{nM})$ in the absence or presence of $1 \mathrm{mM}$ ATP/0.2 mM GTP. (Bottom) Samples were taken at indicated times, and product formation was quantitated with PhosphorImager and plotted against reaction time. The fitting of rates was done with Kaleidagraph software.

\section{Dissociation of RISC activity from Dicer}

How does loading of the miRNA on Ago2 affects its association with Dicer? To address this question 293T cells were doubly transfected with plasmids that expressed myc-Ago2-WT and V5-Dicer (Dicer containing an N-terminal V5 epitope tag), and lysates were prepared and used in immunoprecipitation experiments using anti-V5 or anti-myc monoclonal antibodies; a silver staining of the immunoprecipitates is shown in Supplementary Figure 1. Western blots showed that myc-Ago2 was present in the V5-Dicer immunoprecipitates, and V5-Dicer was present in the myc-Ago2 immunoprecipitates (our unpublished data). The V5-Dicer immunoprecipitates were then subjected to a modified version of our RISC loading assay shown in a schematic form in Figure 7A: after the processing reaction with cold pre-miRNA, the supernatant was separated from the beads, and each fraction was incubated with 5 '-end-labeled target RNA. If RISC activity (i.e., target RNA cleavage) is observed in the supernatant, this would indicate that after premiRNA processing and miRNA loading to Ago2, the Ago2-miRNA ribonucleoprotein is released from the V5Dicer (which is still tethered to the beads through its interactions with the anti-V5 antibody). We first used pre-miR-30a as a substrate and as shown in Figure 7A, the mir-30a-Target was not significantly cleaved by the beads (lane 2) but was mostly cleaved by the supernatant (lanes 3). To rule out the possibility that this was an artifact of the incubation, we set up a reaction containing V5-Dicer immunoprecipitate but not pre-miR-30a. The supernatant from this mock processing reaction was then incubated with pre-miR-30a and then tested for mir-30a-Target cleavage. No cleavage was observed (Fig. $7 \mathrm{~A}$, lane 4), indicating that the binding of the V5-Dicer/ Ago 2 complex to the V5 agarose beads was stable during the reactions.

The RISC loading reaction with the V5-Dicer immunoprecipitates was then tested using PML-GL3 as premiRNA substrate (Fig. 7B), and cleavage activity toward the GL3-Target was found in the supernatant (Fig. 7B, lane 3). However, the beads maintained cleavage activity (Fig. 7B, lane 2), indicating that miRNA-loaded Ago2 that was still associated with Dicer was active. We also prepared supernatant from a mock processing reaction (i.e., V5-Dicer immunoprecipitates not incubated with PML-GL3). Incubation of this mock supernatant with either cold PML-GL3 (Fig. 7B, lane 4), with GL3 siRNA duplex (Fig. 7B, lane 5), or with GL3-24 RNA (Fig. 7B, lane 6) did not lead to GL3-target RNA cleavage. Finally, to confirm that our procedure of separating supernatant from beads did not lead to contamination of supernatant with beads, we applied the modified RISC loading assay to the myc-Ago2 immunoprecipitates from the doubly transfected cells (Fig. 7C). In this case, all target RNA cleavage activity should remain with the beads because myc-Ago 2 is tethered to the agarose resin via its binding to the anti-myc antibody. As shown in Figure 7C, the target RNA cleavage activity did remain with the beads (lane 1) and no activity was found in the supernatant 
Figure 7. RISC activity dissociates from Dicer. 293T cells were doubly transfected with plasmids that express V5-Dicer and myc-Ago2. Immunoprecipitations were done with anti-V5 or with anti-myc antibodies. The immunoprecipitates were used in a modified RISC loading assay in which, after the pre-miRNA processing reaction, the beads and the supernatants were first separated and then tested for cognate target RNA cleavage. (A, left panel) Schematic of the assay. (Right panel) V5Dicer immunoprecipitates were used in the modified RISC loading assay with cold, 5'-phosphorylated premiR-30a. The 5'-end-labeled mir-30a-Target (unreacted in lane 1) was incubated with the beads (lane 2) or with the supernatant (lane 3) after the processing reactions, as well as with a mock supernatant, from a V5-Dicer immunoprecipitate where no substrate had been added to the processing step, but where pre-miR30a was added to the supernatant prior to the target cleavage reaction (lane 4). (B) Cold, 5'-phosphorylated PML-GL3 was used as a processing substrate with the V5-Dicer immunoprecipitates in the modified RISC loading assay. The 5 '-end-labeled PML-GL3-Target (unreacted in lane 1) was incubated with the beads (lane 2) or with the supernatant (lane 3) from the processing reactions, as well as with a mock supernatant, from a V5-Dicer immunoprecipitate where no substrate had been added to the processing step, but where prior to the target cleavage reaction, cold, 5'-phosphorylated PML-GL3 (PML; lane 4), 5'-phosphorylated GL3 siRNA duplex (si; lane 5), or 5'-phosphorylated GL3-24 (as; lane 6) was added. (C, left panel) Schematic of the assay. (Right panel) The mycAgo2 immunoprecipitates were used in the modified RISC loading protocol, with cold, 5'-phosphorylated PML-GL3 as a processing substrate. The $5^{\prime}$-end-labeled PML-GL3-Target was incubated with the beads (lane 1) or with the supernatant (lane 2) from the processing reactions.

(lane 2), showing that the supernatants were not contaminated with beads. We conclude that the RISC activity detected in the supernatants after presenting the V5Dicer immunoprecipitates with pre-miRNAs is due to miRNA-loaded Ago2 that had been dissociated from Dicer.

\section{Discussion}

The experiments presented above demonstrate that the pathway for miRNA loading on human RISCs is different from the one described for siRNA loading on RISCs in flies. In D. melanogaster, siRNA duplexes are first bound to a Dcr-2/R2D2 heterodimer causing the recruitment of Ago2 and the ATP-dependent incorporation of
A
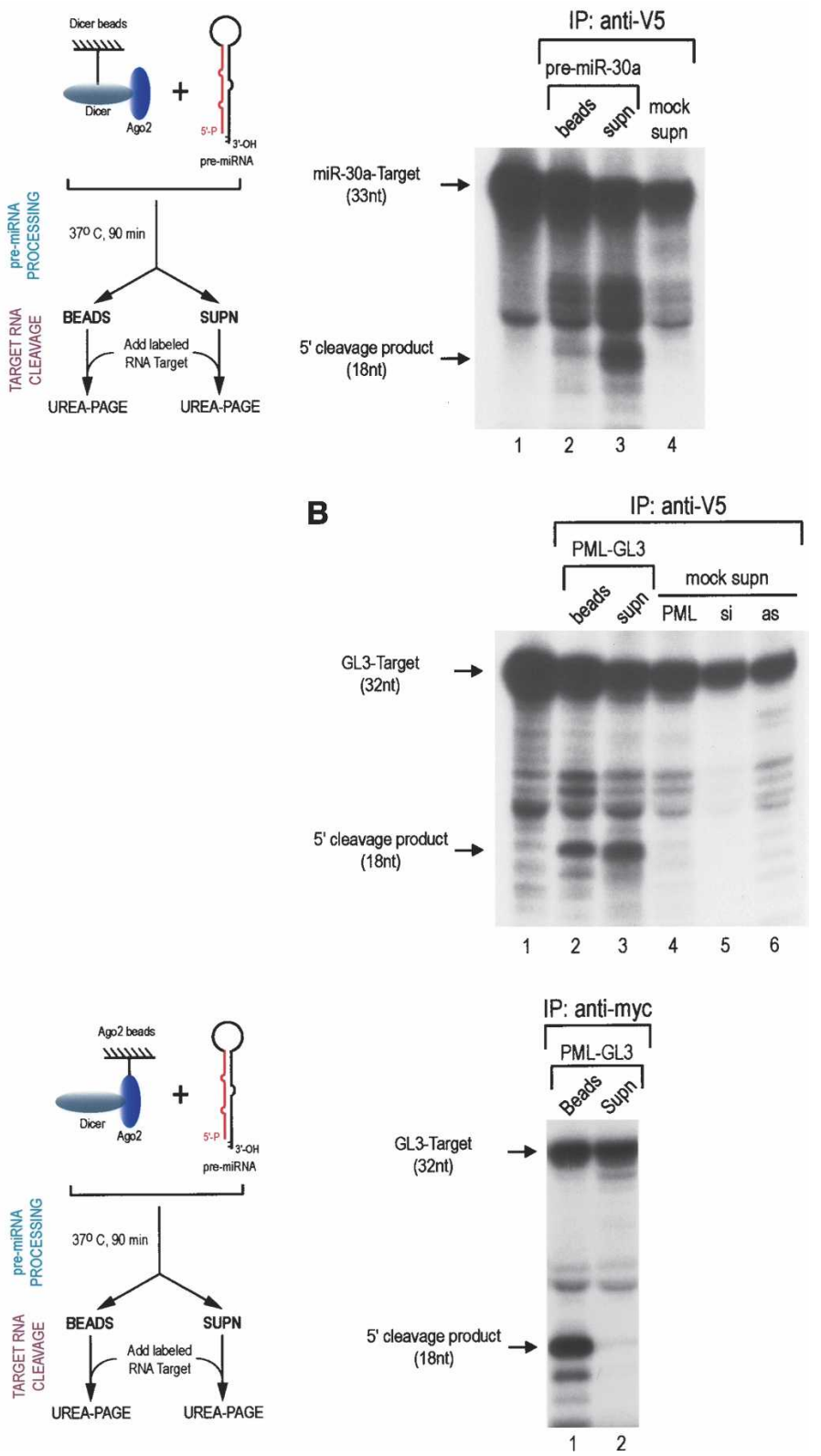

single-stranded siRNAs in holo-RISCs, which still retain Dcr-2/R2D2 (Pham et al. 2004; Tomari et al. 2004b; Tomari and Zamore 2005). In our human immunopurified system, Dicer is already associated with Ago2 prior to its encounter with processing substrate or product. The preformed Ago2/Dicer-containing complex can assemble RISCs from pre-miRNAs but not from siRNA duplexes even when ATP/GTP is added. Furthermore, in our human system, the final RISC product can be released from Dicer.

We favor a model in which human RISC assembly is initiated with pre-miRNA processing, in a human RLC, which we term the human miRNA loading complex (miRLC) (Fig. 8). The miRLC contains Ago2 that has not been loaded yet with miRNAs. Once binding of miRNAs 


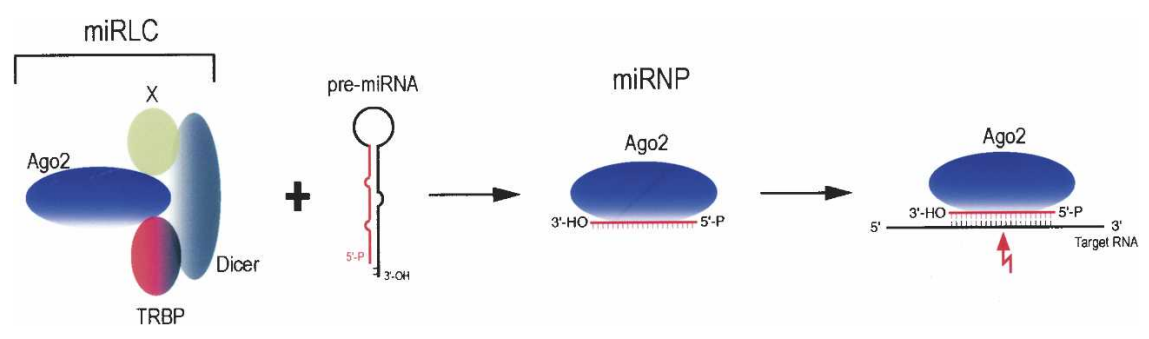

Figure 8. Working model of human RISC assembly from pre-miRNAs. to Ago2 has occurred, it is essentially irreversible and the bound miRNA cannot be exchanged with other miRNAs or siRNAs (Martinez and Tuschl 2004; our unpublished observations). Although some endogenous miRNAs have been found associated with epitope-tagged Ago2 that is introduced in $293 \mathrm{~T}$ cells (Liu et al. 2004), most of this exogenous Ago2 is devoid of miRNAs (Maniataki and Mourelatos 2005) and, as shown here, is engaged in the miRLC.

Besides Ago2, other core components of the human miRLC are Dicer and TRBP (see also Fig. 1; Supplementary Figs. 1, 2). However, additional proteins are likely present in the human miRLC (Fig. 8; additional factors are shown as " $X$ "). We have found that (mt)-tRNA ${ }^{\text {Met }}$ and HSP90 associate with overexpressed human Ago2. Dicer and Ago2 interact directly (Tahbaz et al. 2004), and HSP90 is required for stabilization of Ago2 (Tahbaz et al. 2001). The role of HSP90 and (mt)-tRNA ${ }^{\text {Met }}$, if any, in RISC assembly is unknown. HSP90 and (mt)tRNA $^{\text {Met }}$, but not Dicer, may be removed from the Ago2 immunoprecipitates by extensive washings, and these immunoprecipitates are capable of processing premiRNAs and assembling functional RISCs (our unpublished data), suggesting that HSP90 and (mt)-tRNA ${ }^{\text {Met }}$ may be dispensable for RISC assembly. Perhaps HSP90 or $(\mathrm{mt})$-tRNA ${ }^{\text {Met }}$ plays a role in the in vivo formation or regulation of human miRLCs, or they may have other functions unrelated to RISC assembly or function.

Processing of pre-miRNA by Dicer leads to the formation of a transient "miRNA duplex" intermediate that has very similar structural features with siRNA duplexes (Bartel 2004; Tomari and Zamore 2005). Unwinding of the miRNA duplex gives rise to mature single-stranded miRNA that is eventually bound to Ago 2 and results in formation of active RISC. How does unwinding of the miRNA duplex proceed? It is possible that pre-miRNA processing and miRNA duplex unwinding occur simultaneously with loading of the single-stranded miRNA to Ago2. An alternative possibility is that a single-stranded miRNA is released after Dicer processing and it is captured by Ago2. It is also conceivable that the miRNA duplex is released from Dicer and recaptured by Dicer or by other components of the miRLC before unwinding and Ago2 loading. However, a simple release and recapture mechanism of duplexes would not be sufficient to explain the efficiency of RISC assembly by pre-miRNAs, because addition of siRNA duplex to miRLC does not result in efficient RISC formation. This finding also indicates that the pathway of human RISC assembly by
siRNA duplexes may be distinct from RISC assembly by pre-miRNAs. In fact, the observation that siRNA duplexes can mount an effective RNAi response in Dicernull mouse embryonic stem cells (Kanellopoulou et al. 2005) argues that mammalian Dicer is not required for RISC assembly from siRNA duplexes in vivo. Furthermore, in Dicer-null zebrafish embryos, delivery of miRNAs in the form of siRNA duplexes restores miRNA function (Giraldez et al. 2005), and Dicer is also dispensable for in vitro RISC assembly from siRNA duplexes (Martinez et al. 2002).

It is likely that the human miRLC assembles RISCs only when there is active, concomitant "dicing" of proper precursor RNA molecules: pre-miRNAs or dsRNAs. dsRNA is a suboptimal substrate for the miRLC; pre-miRNAs are processed more efficiently (our unpublished results). Nevertheless, coupling of dicing with unwinding may explain our finding that human RISC assembly by pre-miRNAs does not require ATP. It is possible that the hydrolysis of two phosphodiester bonds per pre-miRNA molecule during Dicer processing provides the energy needed to unwind the miRNA duplex. Alternatively, conformational changes induced during RISC assembly may be sufficient to "unwind" the miRNA duplex (e.g., by accelerating thermal melting of the duplex) without the need for NTP hydrolysis. It is possible that this unwinding is mediated by the Ago2/ Dicer complex or by another, as yet, unidentified molecule present in the miRLC. In flies, Dcr-1 does not require ATP to process pre-miRNAs (Jiang et al. 2005). It is possible that ATP is required for the function of Dicer as a multiple-turnover enzyme in our in vitro system; further work is required to address these issues.

In some cases, including pre-miR-30a, both strands of the miRNA duplex accumulate as mature miRNAs (Lagos-Quintana et al. 2001; Mourelatos et al. 2002; Zeng et al. 2002). However in most cases, only one singlestranded miRNA is loaded into RISC/miRNP and accumulates in cells, while the opposite strand of the duplex, known as $\mathrm{miR}^{\star}$, is destroyed (Bartel 2004; Tomari and Zamore 2005). Pre-let-7a-3 is an example of such asymmetry since only let-7a, and not let- $7 a^{\star}$, is detected in cells. Asymmetric RISC loading is recapitulated in vitro by the human miRLC. In flies, the asymmetry of the siRNA duplex is sensed by R2D2, a dsRBD-containing protein, which recruits Dicer to RISC (Tomari et al. $2004 \mathrm{~b}$ ). How the asymmetry of the pre-miRNAs is sensed is unknown.

What is the fate of the human miRLC after miRNA is 
loaded to Ago2? In flies, the RLC is incorporated into the holo-RISC (Pham et al. 2004; Tomari and Zamore 2005). It is possible that a fraction of human miRLC also incorporates into RISCs/miRNPs. However, our findings (Fig. 7) favor an alternative model in which Dicer can depart after loading of miRNAs to Ago2 (Fig. 8). This model is supported by several additional observations. The Ago2siRNA ribonucleoprotein can function without other proteins in target RNA cleavage (Rivas et al. 2005). Endogenous human or mouse Ago2 that is bound to miRNAs may assemble with other proteins into miRNPs (Mourelatos et al. 2002), but the miRNPs do not contain Dicer (our unpublished results). The Ago2 of miRNPs is catalytically active and can cleave targets that are complementary to its bound miRNAs (Hutvagner and Zamore 2002; Kiriakidou et al. 2005). Affinitypurified human RISCs assembled from siRNA duplexes (siRNPs) have a small size of $\sim 90-160 \mathrm{kDa}$, do not contain Dicer, and are also active against target RNA cleavage (Martinez et al. 2002). In contrast, overexpressed, epitope-tagged Ago2 is mostly devoid of miRNAs (Maniataki and Mourelatos 2005) and associates with Dicer. As shown here, this complex is fully capable of assembling functional RISCs from pre-miRNAs. However, in vitro assembly of RISCs from mammalian extracts is very inefficient (Martinez et al. 2002). The most straightforward interpretation of these observations is that only a limiting amount of miRNA-free Ago2 associates with Dicer into miRLC, since most of the endogenous Ago2 has already been loaded with miRNA and has formed Dicer-free, functional miRNPs.

The miRNP that is assembled in vitro by our RISC loading protocol cleaves the target at rates that are not affected by ATP. Similarly, ATP does not affect target cleavage rates by RISC that is formed by bacterially expressed recombinant human Ago2 and ss siRNA (Rivas et al. 2005). In Drosophila extracts, ATP also does not influence the rates in single turnover reaction conditions; however, ATP enhances multiple turnover by facilitating target release (Haley and Zamore 2004). The finding that ATP does not stimulate the cleavage reaction in our system suggests that the RISC formed functions as a single turnover enzyme. However, further work is required to address how the product is released after target RNA cleavage and to investigate whether additional factors are required for product release.

\section{Materials and methods}

\section{Plasmids and synthetic RNAs}

The Flag-Ago2 cell line is described in Maniataki and Mourelatos (2005). The myc-Ago2 constructs are described in Liu et al. (2004), and the V5-Dicer construct is described in Han et al. (2004). The sequences of the RNAs used (pre-miR30a, PMLGL3, GL3-24, GL3 siRNA duplex, miR-30a-Target, GL3-Target, pre-let-7a-3, let-7a-Target, and let-7a ${ }^{*}$-Target) are shown in Figures 2, 3, 4, and 5. All RNAs were synthesized by Dharmacon.
Tissue culture, transfections, immunoprecipitations, Western blots, Northern blots, 5'-end labeling of RNA,

5'-phosphorylations, $3^{\prime}$-end labeling of RNA with $p C p$, gel purification of RNA

These were performed as previously described (Mourelatos et al. 2002; Nelson et al. 2004; Kiriakidou et al. 2005; Maniataki and Mourelatos 2005; Maniataki et al. 2005). For 3 '-end labeling of pre-let-7a-3, the synthetic pre-let-7a-3 was labeled with $\mathrm{pCp}$ and T4 RNA ligase and was gel-purified and then treated with alkaline phosphatase to remove the 3 '-phosphate of the ligated $\mathrm{pCp}$ and to create a free $3^{\prime}-\mathrm{OH}$. The labeled RNA was then $5^{\prime}$-phosphorylated with T4 polynucleotide kinase and cold ATP.

\section{ATP depletion and ATP concentration measurements}

For ATP depletion, beads were incubated with $0.1 \mathrm{U} / \mu \mathrm{L}$ hexokinase and $20 \mathrm{mM}$ glucose as described in Nykanen et al. (2001). The concentration of ATP was measured using an ATP bioluminescent assay kit purchased from Sigma (FL-AA).

\section{Processing and cleavage assays}

The processing reactions were performed in a total volume of $10.5 \mu \mathrm{L}$ that consisted of $0.5 \mu \mathrm{L}$ of Rnasin, $6 \mu \mathrm{L}$ of $1 \times$ MIB Buffer (40 $\mathrm{mM}$ potassium acetate at $\mathrm{pH} 7.4,2 \mathrm{mM} \mathrm{MgCl} 2,1 \mathrm{mM}$ DTT) (see Kiriakidou et al. 2005), $2 \mu \mathrm{L}$ from the beads/immunoprecipitates, and $2 \mu \mathrm{L}$ of either a preparation of $0.25 \mu \mathrm{M}^{32} \mathrm{P}$-labeled $\left(5^{\prime}\right.$-end labeled) substrate or a preparation of $2 \mu \mathrm{M}$ cold, $5^{\prime}$-phosphorylated substrate; or as otherwise noted in the text. The incubation time was 90-120 min. Before the cleavage reaction, the processing reaction was spun briefly, the supernatant was separated, and the beads were washed twice with $200 \mu \mathrm{L}$ of $1 \times$ MIB. To the washed beads (and in the modified assay, to the supernatants as well), a $10-\mu \mathrm{L}$ cleavage reaction mix was added consisting of $0.5 \mu \mathrm{L}$ of Rnasin, $9 \mu \mathrm{L}$ of $1 \times \mathrm{MIB}$, and $0.5 \mu \mathrm{L}$ of a $0.25 \mu \mathrm{M}$ preparation of ${ }^{32} \mathrm{P}$-labeled target RNA (or as otherwise noted in the text). The incubation time was 90-120 min. In reactions containing ATP/GTP (e.g., Fig. 6), 1 mM ATP and 0.2 mM GTP were used, or as otherwise noted in the text. Quantification of product formation (Fig. 6) was done with PhosphorImager, and rates were fitted with Kaleidagraph software (Synergy), as described in Haley and Zamore (2004) and Rivas et al. (2005).

\section{Acknowledgments}

We are grateful to G. Hannon for the myc-Ago2 constructs; to N. Kim for the V5-Dicer construct; to K. Saigo and W. Filipowicz for anti-Dicer antibodies; to R. Shiekhattar and A. Gatignol for anti-TRBP antibodies; to S. Lambrinaki for plasmid preparations; to T. Nilsen, M. Kiriakidou, P. Nelson, S. Lambrinaki, and X. Liu for comments on the manuscript; and to P. Zamore and members of the Mourelatos laboratory for helpful discussions. This work was supported by NIH grants R01GM0720777, MRDDRC Core (P30-HD026979), NCICCC Core (P30-CA016520), and from the McCabe Foundation, to Z.M.

\section{References}

Ambros, V. 2004. The functions of animal microRNAs. Nature 431: 350-355.

Bartel, D.P. 2004. MicroRNAs: Genomics, biogenesis, mechanism, and function. Cell 116: 281-297.

Bernstein, E., Caudy, A.A., Hammond, S.M., and Hannon, G.J. 
2001. Role for a bidentate ribonuclease in the initiation step of RNA interference. Nature 409: 363-366.

Bohnsack, M.T., Czaplinski, K., and Gorlich, D. 2004. Exportin 5 is a RanGTP-dependent dsRNA-binding protein that mediates nuclear export of pre-miRNAs. RNA 10: 185-191.

Carmell, M.A., Xuan, Z., Zhang, M.Q., and Hannon, G.J. 2002. The Argonaute family: Tentacles that reach into RNAi, developmental control, stem cell maintenance, and tumorigenesis. Genes \& Dev. 16: 2733-2742.

Chendrimada, T.P., Gregory, R.I., Kumaraswamy, E., Norman, J., Cooch, N., Nishikura, K., and Shiekhattar, R. 2005. TRBP recruits the Dicer complex to Ago2 for microRNA processing and gene silencing. Nature 436: 740-744.

Denli, A.M., Tops, B.B., Plasterk, R.H., Ketting, R.F., and Hannon, G.J. 2004. Processing of primary microRNAs by the Microprocessor complex. Nature 432: 231-235.

Doi, N., Zenno, S., Ueda, R., Ohki-Hamazaki, H., Ui-Tei, K., and Saigo, K. 2003. Short-interfering-RNA-mediated gene silencing in mammalian cells requires Dicer and eIF2C translation initiation factors. Curr. Biol. 13: 41-46.

Elbashir, S.M., Lendeckel, W., and Tuschl, T. 2001. RNA interference is mediated by 21 - and 22-nucleotide RNAs. Genes \& Dev. 15: 188-200.

Fire, A., Xu, S., Montgomery, M.K., Kostas, S.A., Driver, S.E., and Mello, C.C. 1998. Potent and specific genetic interference by double-stranded RNA in Caenorhabditis elegans. Nature 391: 806-811.

Forstemann, K., Tomari, Y., Du, T., Vagin, V.V., Denli, A.M., Bratu, D.P., Klattenhoff, C., Theurkauf, W.E., and Zamore, P.D. 2005. Normal microRNA maturation and germ-line stem cell maintenance requires Loquacious, a doublestranded RNA-binding domain protein. PLoS Biol. 3: e236.

Giraldez, A.J., Cinalli, R.M., Glasner, M.E., Enright, A.J., Thomson, J.M., Baskerville, S., Hammond, S.M., Bartel, D.P., and Schier, A.F. 2005. MicroRNAs regulate brain morphogenesis in zebrafish. Science 308: 833-838.

Gregory, R.I., Yan, K.P., Amuthan, G., Chendrimada, T., Doratotaj, B., Cooch, N., and Shiekhattar, R. 2004. The Microprocessor complex mediates the genesis of microRNAs. $\mathrm{Na}$ ture 432: 235-240.

Grishok, A., Pasquinelli, A.E., Conte, D., Li, N., Parrish, S., Ha, I., Baillie, D.L., Fire, A., Ruvkun, G., and Mello, C.C. 2001. Genes and mechanisms related to RNA interference regulate expression of the small temporal RNAs that control C. elegans developmental timing. Cell 106: 23-34.

Haase, A.D., Jaskiewicz, L., Zhang, H., Laine, S., Sack, R., Gatignol, A., and Filipowicz, W. 2005. TRBP, a regulator of cellular PKR and HIV-1 virus expression, interacts with Dicer and functions in RNA silencing. EMBO Rep. 6: 961967.

Haley, B. and Zamore, P.D. 2004. Kinetic analysis of the RNAi enzyme complex. Nat. Struct. Mol. Biol. 11: 599-606.

Hamilton, A.J. and Baulcombe, D.C. 1999. A species of small antisense RNA in posttranscriptional gene silencing in plants. Science 286: 950-952.

Hammond, S.M., Boettcher, S., Caudy, A.A., Kobayashi, R., and Hannon, G.J. 2001. Argonaute2, a link between genetic and biochemical analyses of RNAi. Science 293: 1146-1150.

Han, J., Lee, Y., Yeom, K.H., Kim, Y.K., Jin, H., and Kim, V.N. 2004. The Drosha-DGCR8 complex in primary microRNA processing. Genes \& Dev. 18: 3016-3027.

Hutvagner, G. and Zamore, P.D. 2002. A microRNA in a multiple-turnover RNAi enzyme complex. Science 297: 20562060.

Hutvagner, G., McLachlan, J., Pasquinelli, A.E., Balint, E., Tus- chl, T., and Zamore, P.D. 2001. A cellular function for the RNA-interference enzyme Dicer in the maturation of the let-7 small temporal RNA. Science 293: 834-838.

Jiang, F., Ye, X., Liu, X., Fincher, L., McKearin, D., and Liu, Q. 2005. Dicer-1 and R3D1-L catalyze microRNA maturation in Drosophila. Genes \& Dev. 19: 1674-1679.

Kanellopoulou, C., Muljo, S.A., Kung, A.L., Ganesan, S., Drapkin, R., Jenuwein, T., Livingston, D.M., and Rajewsky, K. 2005. Dicer-deficient mouse embryonic stem cells are defective in differentiation and centromeric silencing. Genes \& Dev. 19: 489-501.

Ketting, R.F., Fischer, S.E., Bernstein, E., Sijen, T., Hannon, G.J., and Plasterk, R.H. 2001. Dicer functions in RNA interference and in synthesis of small RNA involved in developmental timing in C. elegans. Genes \& Dev. 15: 2654-2659.

Khvorova, A., Reynolds, A., and Jayasena, S.D. 2003. Functional siRNAs and miRNAs exhibit strand bias. Cell 115: 209-216.

Kiriakidou, M., Nelson, P., Lamprinaki, S., Sharma, A., and Mourelatos, Z. 2005. Detection of microRNAs and assays to monitor microRNA activities in vivo and in vitro. In $R N A$ silencing methods and protocols (ed. G. Carmichael), pp. 297-312. Humana Press, Totowa, NJ.

Knight, S.W. and Bass, B.L. 2001. A role for the RNase III enzyme DCR-1 in RNA interference and germ line development in Caenorhabditis elegans. Science 293: 2269-2271.

Lagos-Quintana, M., Rauhut, R., Lendeckel, W., and Tuschl, T. 2001. Identification of novel genes coding for small expressed RNAs. Science 294: 853-858.

Landthaler, M., Yalcin, A., and Tuschl, T. 2004. The human DiGeorge syndrome critical region Gene 8 and its D. melanogaster homolog are required for miRNA biogenesis. Curr. Biol. 14: 2162-2167.

Lau, N.C., Lim, L.P., Weinstein, E.G., and Bartel, D.P. 2001. An abundant class of tiny RNAs with probable regulatory roles in Caenorhabditis elegans. Science 294: 858-862.

Lee, R.C. and Ambros, V. 2001. An extensive class of small RNAs in Caenorhabditis elegans. Science 294: 862-864.

Lee, R.C., Feinbaum, R.L., and Ambros, V. 1993. The C. elegans heterochronic gene lin-4 encodes small RNAs with antisense complementarity to lin-14. Cell 75: 843-854.

Lee, Y., Jeon, K., Lee, J.T., Kim, S., and Kim, V.N. 2002. MicroRNA maturation: Stepwise processing and subcellular localization. EMBO J. 21: 4663-4670.

Lee, Y., Ahn, C., Han, J., Choi, H., Kim, J., Yim, J., Lee, J., Provost, P., Radmark, O., Kim, S., et al. 2003. The nuclear RNase III Drosha initiates microRNA processing. Nature 425: 415-419.

Lee, Y., Kim, M., Han, J., Yeom, K.H., Lee, S., Baek, S.H., and Kim, V.N. 2004a. MicroRNA genes are transcribed by RNA polymerase II. EMBO I. 23: 4051-4060.

Lee, Y.S., Nakahara, K., Pham, J.W., Kim, K., He, Z., Sontheimer, E.J., and Carthew, R.W. 2004b. Distinct roles for Drosophila Dicer-1 and Dicer-2 in the siRNA/miRNA silencing pathways. Cell 117: 69-81.

Liu, J., Carmell, M.A., Rivas, F.V., Marsden, C.G., Thomson, J.M., Song, J.J., Hammond, S.M., Joshua-Tor, L., and Hannon, G.J. 2004. Argonaute 2 is the catalytic engine of mammalian RNAi. Science 305: 1437-1441.

Lund, E., Guttinger, S., Calado, A., Dahlberg, J.E., and Kutay, U. 2004. Nuclear export of microRNA precursors. Science 303: 95-98.

Maniataki, E. and Mourelatos, Z. 2005. Human mitochondrial tRNA $^{\text {Met }}$ is exported to the cytoplasm and associates with the Argonaute 2 protein. RNA 11: 849-852.

Maniataki, E., De Planell-Saguer, M., and Mourelatos, Z. 2005. 
Immunoprecipitation of microRNPs and directional cloning of microRNAs. In RNA silencing methods and protocols (ed. G. Carmichael), pp. 285-296. Humana Press, Totowa, NJ.

Martinez, J. and Tuschl, T. 2004. RISC is a 5' phosphomonoester-producing RNA endonuclease. Genes \& Dev. 18: 975980.

Martinez, J., Patkaniowska, A., Urlaub, H., Luhrmann, R., and Tuschl, T. 2002. Single-stranded antisense siRNAs guide target RNA cleavage in RNAi. Cell 110: 563-574.

Meister, G. and Tuschl, T. 2004. Mechanisms of gene silencing by double-stranded RNA. Nature 431: 343-349.

Meister, G., Landthaler, M., Patkaniowska, A., Dorsett, Y., Teng, G., and Tuschl, T. 2004. Human Argonaute2 mediates RNA cleavage targeted by miRNAs and siRNAs. Mol. Cell 15: 185-197.

Mourelatos, Z., Abel, L., Yong, J., Kataoka, N., and Dreyfuss, G. 2001. SMN interacts with a novel family of hnRNP and spliceosomal proteins. EMBO J. 20: 5443-5452.

Mourelatos, Z., Dostie, J., Paushkin, S., Sharma, A., Charroux, B., Abel, L., Rappsilber, J., Mann, M., and Dreyfuss, G. 2002. miRNPs: A novel class of ribonucleoproteins containing numerous microRNAs. Genes \& Dev. 16: 720-728.

Murchison, E.P. and Hannon, G.J. 2004. miRNAs on the move: miRNA biogenesis and the RNAi machinery. Curr. Opin. Cell Biol. 16: 223-229.

Nelson, P., Kiriakidou, M., Sharma, A., Maniataki, E., and Mourelatos, Z. 2003. The microRNA world: Small is mighty. Trends Biochem. Sci. 28: 534-540.

Nelson, P.T., Hatzigeorgiou, A.G., and Mourelatos, Z. 2004. miRNP:mRNA association in polyribosomes in a human neuronal cell line. RNA 10: 387-394.

Nykanen, A., Haley, B., and Zamore, P.D. 2001. ATP requirements and small interfering RNA structure in the RNA interference pathway. Cell 107: 309-321.

Okamura, K., Ishizuka, A., Siomi, H., and Siomi, M.C. 2004. Distinct roles for Argonaute proteins in small RNA-directed RNA cleavage pathways. Genes \& Dev. 18: 1655-1666.

Pham, J.W., Pellino, J.L., Lee, Y.S., Carthew, R.W., and Sontheimer, E.J. 2004. A Dicer-2-dependent 80s complex cleaves targeted mRNAs during RNAi in Drosophila. Cell 117: 8394.

Rand, T.A., Ginalski, K., Grishin, N.V., and Wang, X. 2004. Biochemical identification of Argonaute 2 as the sole protein required for RNA-induced silencing complex activity. Proc. Natl. Acad. Sci. 101: 14385-14389.

Reinhart, B.J., Slack, F.J., Basson, M., Pasquinelli, A.E., Bettinger, J.C., Rougvie, A.E., Horvitz, H.R., and Ruvkun, G. 2000. The 21-nucleotide let-7 RNA regulates developmental timing in Caenorhabditis elegans. Nature 403: 901-906.

Rivas, F.V., Tolia, N.H., Song, J.J., Aragon, J.P., Liu, J., Hannon, G.J., and Joshua-Tor, L. 2005. Purified Argonaute2 and an siRNA form recombinant human RISC. Nat. Struct. Mol. Biol. 12: 340-349.

Saito, K., Ishizuka, A., Siomi, H., and Siomi, M.C. 2005. Processing of pre-microRNAs by the Dicer-1-Loquacious complex in Drosophila cells. PLoS Biol. 3: e235.

Schwarz, D.S., Hutvagner, G., Haley, B., and Zamore, P.D. 2002. Evidence that siRNAs function as guides, not primers, in the Drosophila and human RNAi pathways. Mol. Cell 10: $537-$ 548.

Schwarz, D.S., Hutvagner, G., Du, T., Xu, Z., Aronin, N., and Zamore, P.D. 2003. Asymmetry in the assembly of the RNAi enzyme complex. Cell 115: 199-208.

Song, J.J., Smith, S.K., Hannon, G.J., and Joshua-Tor, L. 2004. Crystal structure of Argonaute and its implications for RISC slicer activity. Science 305: 1434-1437.

Tahbaz, N., Carmichael, J.B., and Hobman, T.C. 2001. GERp95 belongs to a family of signal-transducing proteins and requires Hsp90 activity for stability and Golgi localization. J. Biol. Chem. 276: 43294-43299.

Tahbaz, N., Kolb, F.A., Zhang, H., Jaronczyk, K., Filipowicz, W., and Hobman, T.C. 2004. Characterization of the interactions between mammalian PAZ PIWI domain proteins and Dicer. EMBO Rep. 5: 189-194.

Tomari, Y. and Zamore, P.D. 2005. Perspective: Machines for RNAi. Genes \& Dev. 19: 517-529.

Tomari, Y., Du, T., Haley, B., Schwarz, D.S., Bennett, R., Cook, H.A., Koppetsch, B.S., Theurkauf, W.E., and Zamore, P.D. 2004a. RISC assembly defects in the Drosophila RNAi mutant armitage. Cell 116: 831-841.

Tomari, Y., Matranga, C., Haley, B., Martinez, N., and Zamore, P.D. 2004b. A protein sensor for siRNA asymmetry. Science 306: $1377-1380$.

Yi, R., Qin, Y., Macara, I.G., and Cullen, B.R. 2003. Exportin-5 mediates the nuclear export of pre-microRNAs and short hairpin RNAs. Genes \& Dev. 17: 3011-3016.

Zeng, Y. and Cullen, B.R. 2004. Structural requirements for premicroRNA binding and nuclear export by Exportin 5 . Nucleic Acids Res. 32: 4776-4785.

Zeng, Y., Wagner, E.J., and Cullen, B.R. 2002. Both natural and designed micro RNAs can inhibit the expression of cognate mRNAs when expressed in human cells. Mol. Cell 9: 13271333.

Zhang, H., Kolb, F.A., Jaskiewicz, L., Westhof, E., and Filipowicz, W. 2004. Single processing center models for human Dicer and bacterial RNase III. Cell 118: 57-68. 


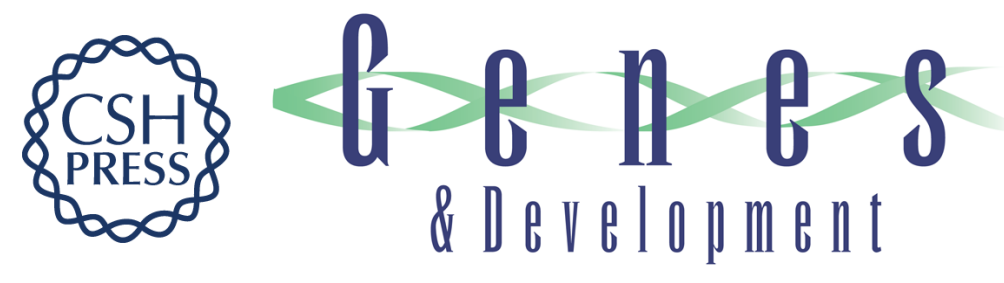

\section{A human, ATP-independent, RISC assembly machine fueled by pre-miRNA}

Elisavet Maniataki and Zissimos Mourelatos

Genes Dev. 2005, 19:

Access the most recent version at doi:10.1101/gad.1384005

\section{Supplemental http://genesdev.cshlp.org/content/suppl/2005/11/30/19.24.2979.DC1 Material}

References This article cites 66 articles, 33 of which can be accessed free at: http://genesdev.cshlp.org/content/19/24/2979.full.html\#ref-list-1

\section{License}

Email Alerting

Receive free email alerts when new articles cite this article - sign up in the box at the top Service

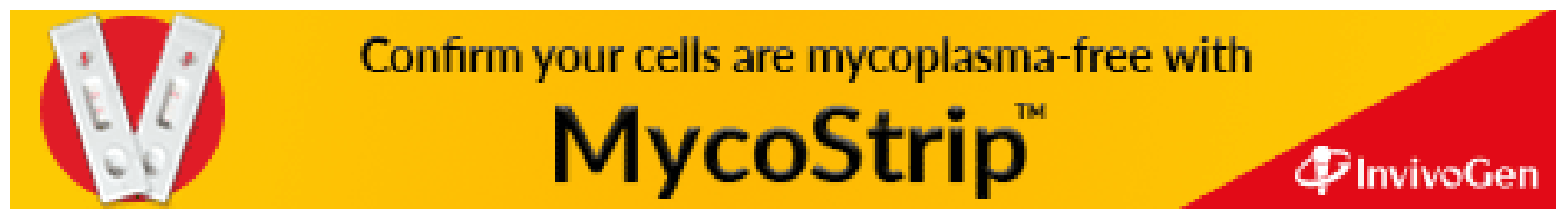

